\title{
Safety and Effectiveness of Total versus Subtotal Thyroidectomy in Management of Simple Multinodular Goiter
}

\author{
ABDELRAHMAN M. ELGHANDOUR, M.D.; OSAMA F. MOHAMED, M.D. and \\ MOHAMED M. TAHER KAMAL EID, M.Sc.
}

The Department of General Surgery, Faculty of Medicine, Ain Shams University

\begin{abstract}
Background: Disorders of the thyroid gland constitute the second most common endocrine disease following diabetes mellitus. The prevalence of nodular goiter and thyroid autonomy is increased in regions with chronic Iodine Deficiency (ID). It has been documented that the thyroid gland adjusts to ID in the early stages by diffuse hyperplasia, while chronic exposure to ID results in nodular hyperplasia, increased colloid content and increased height of the follicular cells.
\end{abstract}

Aim of Study: To compare between total and subtotal thyroidectomy in management of Multinodular Goiter as regard safety and effectiveness and post-operative complications like: Hypocalcaemia, recurrent laryngeal nerve injury and hypoparathyroidism.

Material and Methods: This prospective study was done at Ain Shams University Hospitals and Banha teaching hospital during the period between March and September 2019. This study included 40 cases of SMNG. Their age was between 30 to 45 years, consent was taken from each patient preoperatively. Agreement of ethical committee was done.

Results: Our study showed the advantages of total thyroidectomy include adequate eradication of the disease, prevention of recurrent goiter and avoidance of the need for completion surgery in case of occult malignancy, but it is associated with higher morbidity (postoperative thyroidectomy complications: RLN palsy and hypoparathyroidism) and the need for lifelong replacement therapy (L-thyroxin supplementation).

Conclusion: In MNG, there are a high percentage of cases with disease involving the entire gland; many areas of apparently healthy tissue are found to be microscopically involved with variable grade of chronic lymphocytic thyroiditis or follicular hyperplasia or even lobular dysplasia with tendency to form nodules. These signs of disease of this organ tend to recurrence if not treated.

Key Words: Iodine deficiency - Total thyroidectomy - Bilateral subtotal thyroidectomy.

Correspondence to: Dr. Mohamed M. Taher Kamal Eid, E-Mail: dark89knight2014@gmail.com

\section{Introduction}

DISORDERS of the thyroid gland constitute the second most common endocrine disease following diabetes mellitus. The prevalence of nodular goiter and thyroid autonomy is increased in regions with chronic Iodine Deficiency (ID). It has been documented that the thyroid gland adjusts to ID in the early stages by diffuse hyperplasia, while chronic exposure to ID results in nodular hyperplasia, increased colloid content and increased height of the follicular cells [1].

Multinodular goiter is a common clinical problem that usually develops during the late stage of goiter. Although it is usually benign and asymptomatic in nature, multinodular goiter may predispose the patient to compressive symptoms, develops autonomous functioning nodules, or form suspicious nodules. The clinical treatment of goiter depends on the extent of enlargement, signs and symptoms, and potential underlying causes [2].

Thyroidectomy methods range from nodulectomy to total thyroidectomy (TT) in benign thyroid disorders. TT and bilateral subtotal thyroidectomy (BST) are the most commonly preferred methods by surgeons for MNG. The selected surgical method for thyroid disease should aim to eradicate the disease as well as to minimize postoperative complications [3].

Total thyroidectomy is designed to remove the entire gland leaving behind only viable parathyroid glands [4]. Subtotal thyroidectomy means the bilateral removal of the thyroid tissue including the isthmus with residual bilateral $3 \mathrm{~g}$ remnants of healthy thyroid tissue [5]. 


\section{Advantages of total thyroidectomy:}

- Total thyroidectomy is the procedure of choice for the surgical management of benign multinodular goiter especially in endemic regions [6].

- Total thyroidectomy removes the disease process completely, lowers local recurrence rates and avoids the substantial risks of re-operative surgery $\left.{ }^{7}\right]$.

- Total thyroidectomy is safe and is associated with a low incidence of disabilities. Complication rates for recurrent laryngeal nerve palsy and hypoparathyroidism are similar to results of specialist endocrine surgery units. Total thyroidectomy has the advantages of immediate and permanent cure and no recurrences [8]

\section{Disadvantages of total thyroidectomy:}

- The need for hospitalization for an invasive procedure, the risks of recurrent laryngeal nerve palsy and hypoparathyroidism, the variable cosmetic result, and the individually variable impairment of quality of life under thyroid hormone replacement therapy [9].

- Special attention has to be paid to the pyramidal lobe to avoid leavings of residual tissue and should be regarded as a normal component of the thyroid [10]

\section{Advantages of subtotal thyroidectomy:}

- Avoiding RLN injury during thyroid surgery in case of failure to identify its course. Decrease the rate of hypoparathyroidism by lowering the rate of injury to parathyroid glands during excision [11]

- The limited access to postoperative thyroid hormone replacement medications such as levothyroxine [5]

\section{Disadvantages of subtotal thyroidectomy:}

- The incidence of regrowth of thyroid tissue after partial or less than total thyroidectomy for multinodular goiter is between 12 and 20 percent [12]

- Re operation for recurrent goiter has an increased risk of complications, such as recurrent laryngeal nerve (RLN) injury and hypoparathyroidism, when compared with thyroid surgery at the first time [13].

- Korun et al. [14] reported that $40 \%$ of their patients with multi-nodular goiter have nodules localized in the dorsal part of the gland, which are usually left during normal subtotal resection.

\section{Aim of the work:}

To compare between total and subtotal thyroidectomy in management of Multinodular Goiter as regard safety and effectiveness and post-operative complications like: Hypocalcaemia, recurrent laryngeal nerve injury and hypoparathyroidism.

\section{Material and Methods}

This prospective study was done at Ain Shams University Hospitals and Banha teaching hospital during the period between March and September 2019. This study included 40 cases of SMNG. Their age was between 30 to 45 years, consent was taken from each patient pre-operatively. Agreement of ethical committee was done.

Inclusion criteria: All patients with simple multinodular goitre (SMNG) between 30 to $45 \mathrm{y}$ were included in the study.

Exclusion criteria: Any patient above 45 year or below 30 year, Toxic Goitre, Recurrent Goitre, Autoimmune thyroiditis, Vocal cord paralysis prior to surgery, Malignancy \& Pregnancy.

\section{The surgical procedures:}

Twenty cases were submitted to total thyroidectomy and the other twenty were submitted to subtotal thyroidectomy.

\section{Patient positioning:}

The patient is placed in the supine position on the operating room table with slight extension of the neck $\left(10-15^{\circ}\right)$ by placing a gel roll supporting the shoulder blades. Both arms are tucked to the patient's sides.

\section{Exposure of the thyroid gland:}

A transverse cervical incision is used most commonly for either thyroid lobectomy or total thyroidectomy. The incision is made in the direction of Langer's lines in order to minimize scarring and improve the cosmetic appearance of the scar. The incision is carried through the platysma, and then superior and inferior subplatysmal flaps are raised.

The midline fascia between the strap muscles is divided then the sternohyoid and sternothyroid muscles are separated by blunt dissection. Blunt dissection is carried out until the internal jugular vein and ansa cervicalis nerve are identified. Separating the sternohyoid from the sternothyroid muscles allows for mobilization of the thyroid through a short transverse incision without transecting the strap muscles. Thyroid Richardson retractors or lateral retractors are used to expose the thyroid gland.

\section{In total thyroidectomy:}

The thyroid is retracted anteriorly and medially and the carotid sheath laterally; this retraction 
places tension on the middle thyroid veins and helps expose the area posterolateral to the thyroid where the Para Thyroid Glands and the RLNs are situated. The middle thyroid veins are divided to give better exposure behind the superior portion of the thyroid lobe.

Mobilization of Thyroid Gland and Identification of Upper PTGs:

Dissection is performed superiorly, laterally, and posteriorly with a small peanut sponge on a clamp. The superior thyroid artery (STA) and veins are identified by retracting the thyroid inferiorly and medially. They are individually identified and divided low on the thyroid gland to prevent injury of the External branch of Superior Laryngeal Nerve (EBSLN) (Fig. 1).

The tissues lateral to the upper lobe of the thyroid and medial to the carotid sheath can be mobilized caudally to the cricothyroid muscle (Fig. 2); the RLN enters the cricothyroid muscle at the level of the cricoid cartilage, first passing through Berry's ligament. The upper PTG is often identified at the level of the cricoid cartilage.

When the thyroid lobe is further mobilized, the lower PTG is usually seen anterior to the RLN, usually inferior to where the Inferior Thyroid Artery (ITA) crosses the RLN. The carotid sheath is retracted laterally, and the thyroid gland is retracted anteriorly and medially to facilitate identification of the RLN (Fig. 3). The nerve is situated more medially on the left (running in the tracheoesophageal groove) and more obliquely on the right.

In some patients, the peduncle of Zuckerkandl, a small protuberance of thyroid tissue on the right, tends to obscure the RLN at the level of Berry's ligament. Fatty and lymphatic tissues immediately adjacent to the thyroid gland are swept from it with a peanut sponge on a clamp, and small vessels are ligated. No tissue should be transected until one is sure that it is not the RLN.

The upper PTGs are usually situated on each side of the thyroid gland at the level where the RLN enters the cricothyroid muscle. Because the RLN enters the cricothyroid muscle at the level of the cricoid cartilage, the area vertical to the cricoid cartilage is relatively safe.

\section{Mobilization of pyramidal lobe:}

The pyramidal lobe is found in about $80 \%$ of patients. It extends in a vertical direction, often through the notch in the thyroid cartilage to the hyoid bone. The pyramidal lobe is mobilized by retracting it caudally and by dissecting adjacent to it in a vertical direction. Small vessels are coagulated or ligated (Fig. 4).

\section{Thyroid resection:}

Once the PTGs have been carefully swept or dissected from the thyroid gland and the RLN has been identified, the thyroid lobe can be quickly resected. For TT, the same operation is done again on the other side.

\section{In subtotal thyroidectomy:}

The sternohyoid and the sternothyroid muscles are pulled outwards from the gland by the using of a retractor. Inserting the two forefingers side by side to the outer side of the gland and separating them facilitated the delivery of the gland, thus freeing the gland without injuring the blood vessels.

The upper pole of each lobe is now freed, and to avoid injury to the external laryngeal nerve the superior thyroid vessels are ligated and divided within the pole. The middle thyroid vein is divided and the lobe rotated medially to expose the inferior thyroid artery which is ligated in continuity well away from the gland. The RLN is exposed just below the branches of the inferior thyroid artery, and the inferior thyroid veins are divided, taking care to avoid injury to the nerve.

The devascularized lobe is now delivered into the wound and both lobes with the isthmus and pyramidal lobe are removed, leaving the posterior capsule intact on a thin wedge of thyroid tissue with the parathyroid and RLNs. The cut edge of the capsule is then carefully sutured to the tracheal sheath and bleeding points are secured by ligation or transfixion to obtain perfect hemostasis.

\section{Closure:}

The final step before removing the thyroid is to separate the gland from the anterior surface of the trachea by dividing Berry's ligament. After careful hemostasis, the wound is closed in layers with a suction drain in situ. All patients were given postoperative intravenous antibiotics for a period of 24 hours.

\section{Post-operative care:}

The duration of a thyroid operation is $1-3 \mathrm{~h}$, depending on the size and invasiveness of the goiter, its vascularity, and the location of the PTGs. Post-operatively, the patient is kept in a low Fowler position with the head and shoulders elevated $10^{\circ}$ to $20^{\circ}$ for $6-12 \mathrm{~h}$ to maintain negative pressure in the veins. The patient typically resumes eating within 3-4h, and an antiemetic is ordered as needed. 


\section{Statistical analysis:}

Data were collected, revised, coded and entered to the Statistical Package for Social Science (IBM SPSS) version 23 and the following will be done: Qualitative data were presented as number and percentages while quantitative data were presented as mean, standard deviations and ranges. The comparison between two independent groups with quantitative data and parametric distribution was done by using Independent $t$-test. $p>0.05$ : Non significant, $p<0.05$ : Significant, $p<0.01$ : Highly significant.

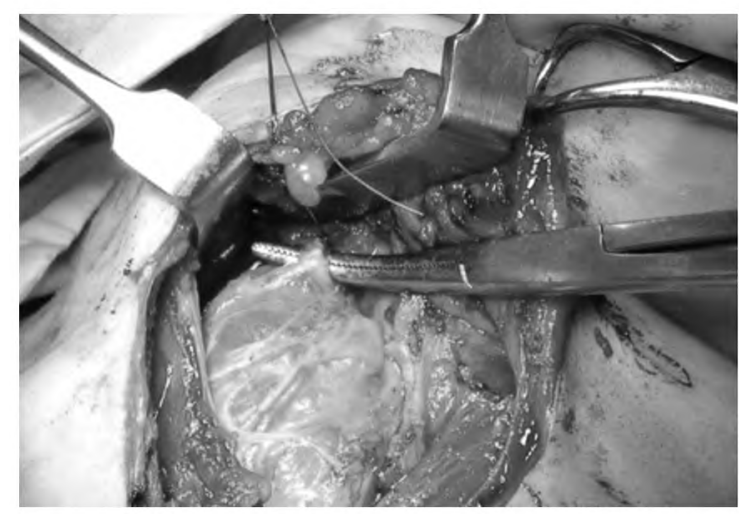

Fig. (1): The STA is individually identified and divided low on the thyroid gland.

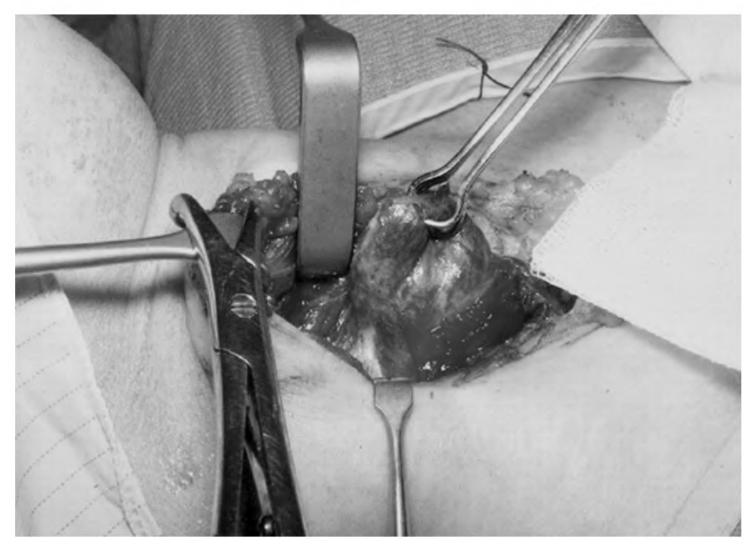

Fig. (2): Mobilizing the upper part of the thyroid lobe caudally to the cricothyroid muscle.

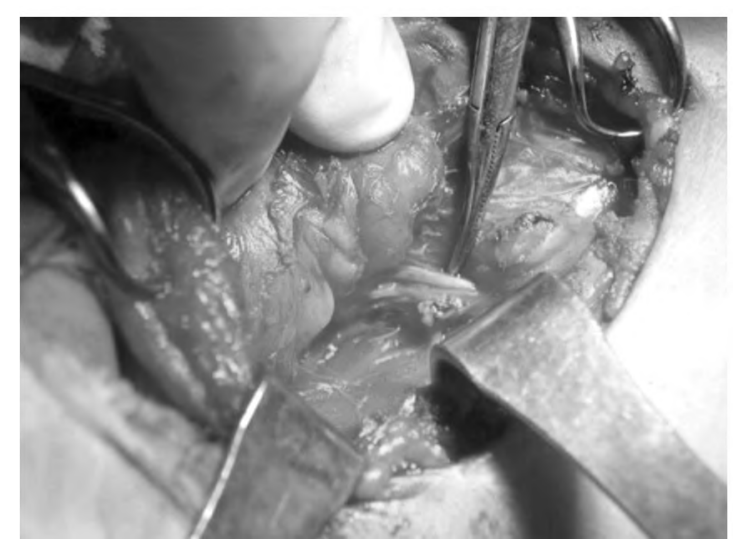

Fig. (3): Identification and dissection of the RLN.

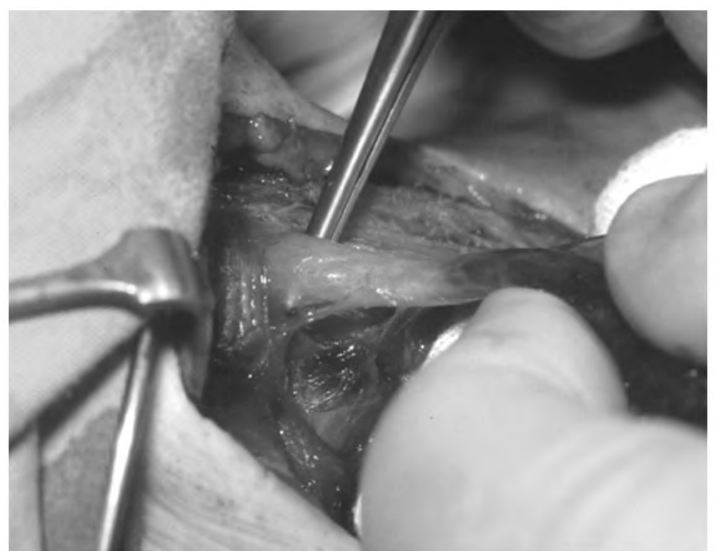

Fig. (4): Mobilization of the pyramidal lobe.

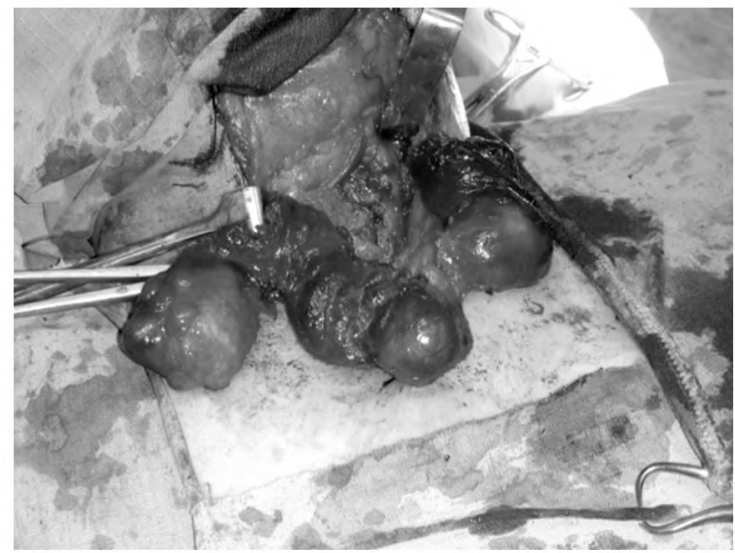

Fig. (5): The delivery of the gland.

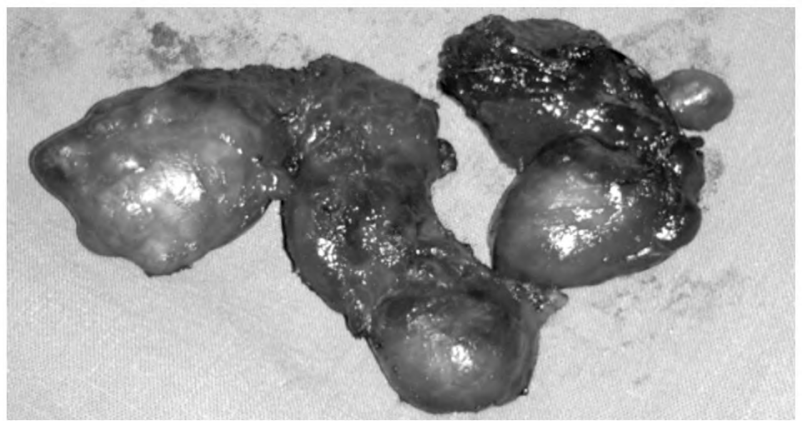

Fig. (6): Specimen No. 1 after subtotal thyroidectomy.

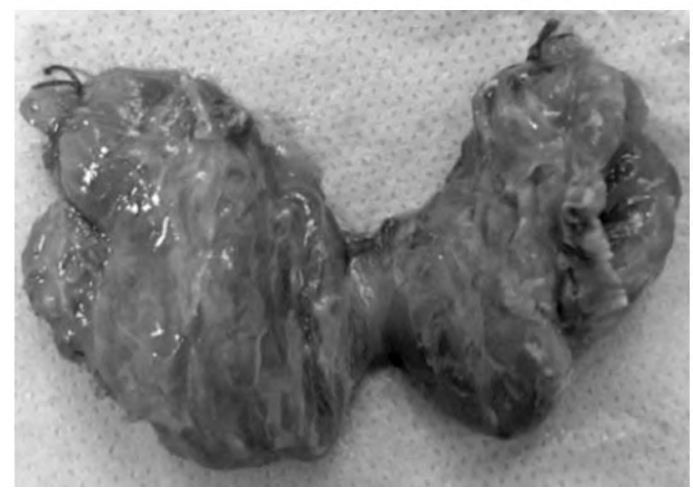

Fig. (7): Specimen No. 2 after total thyroidectomy. 


\section{Results}

In Table (1), group A involved 20 cases of multinodular goiter were managed by total thyroidectomy, in group B 20 cases were managed by subtotal thyroidectomy. The mean operating time was $149.6 \mathrm{~min} \pm 25.01$ in the total thyroidectomy group compared to $134.5 \mathrm{~min}$. \pm 21.94 in subtotal thyroidectomy.

Table (1): Comparison between the studied groups regarding demographic data.

\begin{tabular}{|c|c|c|c|c|c|}
\hline & \multicolumn{2}{|c|}{ Studied techniques } & \multicolumn{2}{|c|}{ Test } & \multirow[b]{2}{*}{$t$} \\
\hline & $\begin{array}{c}\text { Total } \\
\text { thyroid- } \\
\text { ectomy } \\
\mathrm{N}=20(\%)\end{array}$ & $\begin{array}{c}\text { Subtotal } \\
\text { thyroid- } \\
\text { ectomy } \\
\mathrm{N}=20(\%)\end{array}$ & $\begin{array}{c}p- \\
\text { value }\end{array}$ & $\begin{array}{l}\text { Signifi- } \\
\text { cance }\end{array}$ & \\
\hline \multicolumn{6}{|l|}{ Gender: } \\
\hline Male & $7(35)$ & $6(30)$ & 0.736 & NS & \\
\hline Female & $13(65)$ & $14(70)$ & & & \\
\hline \multicolumn{6}{|l|}{ Age (years): } \\
\hline Mean \pm SD & $40.4 \pm 4.30$ & $39.25 \pm 4.06$ & 0.083 & NS & \\
\hline Range & $30-45$ & $35-45$ & & & \\
\hline \multicolumn{6}{|c|}{ Hormonal status: } \\
\hline Euthyroidism & $20(100)$ & $20(100)$ & $<0.999$ & NS & \\
\hline \multicolumn{6}{|l|}{$\begin{array}{l}\text { Operative time } \\
\text { (minutes): }\end{array}$} \\
\hline Mean \pm SD & $149.6 \pm 25.01$ & $134.5 \pm 21.94$ & 0.05 & NS & 2.03 \\
\hline Range & $123-212$ & $110-175$ & & & \\
\hline
\end{tabular}

NS: Statistically non-significant. $\quad t$ : Independent sample $t$-test.

There is statistically non-significant difference between both groups regarding age, gender, hormonal status or operative time. Larger percentages of the studied patients were females $(65 \%$ versus $70 \%$ ). Age of patients underwent total thyroidectomy ranged between 30 and 45 years with mean 40.4 while that of patients underwent subtotal thyroidectomy 39.25 (ranged from 35 to 45 years). Mean operative time in total thyroidectomy (149.6 minutes) was non-significantly higher in subtotal thyroidectomy (134.5 minutes).

Table (2): Comparison between the studied groups regarding general complications.

\begin{tabular}{|c|c|c|c|c|}
\hline \multirow[b]{2}{*}{$\begin{array}{l}\text { General } \\
\text { complications }\end{array}$} & \multicolumn{2}{|c|}{ Studied techniques } & \multicolumn{2}{|r|}{ Test } \\
\hline & $\begin{array}{c}\text { Total } \\
\text { thyroid- } \\
\text { ectomy } \\
\mathrm{N}=20(\%)\end{array}$ & $\begin{array}{c}\text { Subtotal } \\
\text { thyroid- } \\
\text { ectomy } \\
\mathrm{N}=20(\%)\end{array}$ & $\begin{array}{c}p- \\
\text { value }\end{array}$ & Significance \\
\hline Hematoma: & & & & \\
\hline $\begin{array}{l}\text { No } \\
\text { Yes }\end{array}$ & $\begin{array}{l}19(95) \\
1(5)\end{array}$ & $\begin{array}{l}20(100) \\
0(0)\end{array}$ & $>0.999$ & NS \\
\hline $\begin{array}{l}\text { Wound site infection: } \\
\text { No }\end{array}$ & $20(100)$ & $20(100)$ & $>0.999$ & NS \\
\hline
\end{tabular}

NS: Statistically non-significant.
There is statistically non-significant difference between the studied surgical techniques regarding hematoma and wound site infection. Only one patient (5\%) from those underwent total thyroidectomy had hematoma. No one of patients within both techniques had wound site infection.

Only one case was complicated by postoperative hematoma 1 hour after surgery in group A. The patient re-entered the operation room again where hematoma was found due to slipped suture. Hematoma was evacuated immediately re-ligation of the vessel with good hemostasis, the patient improved without any other complications. No patient in group B had post-operative local complications. No patient in both groups had postoperative wound site infection.

Table (3): Comparison between the studied groups regarding specific complications.

\begin{tabular}{|c|c|c|c|c|}
\hline \multirow[b]{2}{*}{$\begin{array}{l}\text { Specific } \\
\text { complications }\end{array}$} & \multicolumn{2}{|c|}{ Studied techniques } & \multicolumn{2}{|c|}{ Test } \\
\hline & $\begin{array}{c}\text { Total } \\
\text { thyroid- } \\
\text { ectomy } \\
\mathrm{N}=20(\%)\end{array}$ & $\begin{array}{l}\text { Subtotal } \\
\text { thyroid- } \\
\text { ectomy } \\
\mathrm{N}=20(\%)\end{array}$ & $\begin{array}{c}p- \\
\text { value }\end{array}$ & Sig. \\
\hline RLN palsy: & & & & \\
\hline $\begin{array}{c}\text { Transient: } \\
\text { No } \\
\text { Yes }\end{array}$ & $\begin{array}{l}19(95) \\
1(5)\end{array}$ & $\begin{array}{l}20(100) \\
0(0)\end{array}$ & $>0.999$ & NS \\
\hline $\begin{array}{l}\text { Permanent: } \\
\text { No }\end{array}$ & $20(100)$ & $20(100)$ & $>0.999$ & NS \\
\hline $\begin{array}{l}\text { Hypocalcaemia } \\
\text { Transient: }\end{array}$ & & & & \\
\hline $\begin{array}{l}\text { No } \\
\text { Yes }\end{array}$ & $\begin{array}{l}19(95) \\
1(5)\end{array}$ & $\begin{array}{l}20(100) \\
0(0)\end{array}$ & $>0.999$ & NS \\
\hline $\begin{array}{c}\text { Permanent: } \\
\text { No } \\
\text { Yes }\end{array}$ & $\begin{array}{l}19(95) \\
1(5)\end{array}$ & $\begin{array}{l}20(100) \\
0(0)\end{array}$ & $>0.999$ & NS \\
\hline $\begin{array}{l}\text { Hypoparathyroi } \\
\text { Transient: }\end{array}$ & & & & \\
\hline $\begin{array}{l}\text { No } \\
\text { Yes }\end{array}$ & $\begin{array}{l}20(100) \\
0(0)\end{array}$ & $\begin{array}{l}20(100) \\
0(0)\end{array}$ & $>0.999$ & NS \\
\hline $\begin{array}{c}\text { Permanent: } \\
\text { No } \\
\text { Yes }\end{array}$ & $\begin{array}{l}19(95) \\
1(5)\end{array}$ & $\begin{array}{l}20(100) \\
0(0)\end{array}$ & $>0.999$ & NS \\
\hline
\end{tabular}

NS: Statistically non-significant.

There is statistically non-significant difference between the studied surgical techniques regarding occurrence of RLN palsy, postoperative hypocalcaemia and postoperative hypoparathyroidism. Only one patient (5\%) from those underwent total thyroidectomy had transient RLN palsy. No one of patients within both techniques had permanent RLN palsy. One patient (5\%) had transient and another one $(5 \%)$ had permanent hypocalcaemia underwent total thyroidectomy. No patient $(0 \%)$ 
underwent subtotal thyroidectomy had transient or permanent hypocalcaemia. One patient $(5 \%)$ underwent total thyroidectomy versus no patient underwent subtotal thyroidectomy had permanent hypocalcaemia.

Regarding the patient who had unilateral RLN injury, this patient had hoarseness of voice and mild dysphagia. Direct laryngoscope was done and showed limited vocal cord movement then the patient was referred to an otolaryngologist. Treatment strategies included voice rehabilitation, speech therapy and vocal cord augmentation using injection by laryngologist. The patient started to improve after 6 months post operatively.

Regarding patient who had temporary hypocalcaemia blood sample was taken for total and ionized $\mathrm{Ca}++$ analysis and reveled mild decrease in serum calcium (total calcium $=8.7$, ionized calcium $=$ 4.4). We gave the patient calcium supplement I.V (10cc of intravenous $10 \%$ calcium gluconate solution infused over 30 minutes) and oral calcium carbonate was prescribed. The patient gradually improved and calcium level returned to normal levels.

Regarding patient who had permanent hypocalcaemia blood sample was taken for total and ionized $\mathrm{Ca}++$ analysis one week after the operation and reveled mild decrease in serum calcium (total calcium $=8.5$, ionized calcium $=4.5$ ). After another 3 weeks there was marked decrease in calcium level (total calcium $=7.3$, ionized calcium $=3.5$ ) the patient had carpopedal spasm so we admitted the patient in the ICU and ordered for more lab investigation especially parathyroid hormone level (PTH level less than $5 \mathrm{pg} / \mathrm{ml}$ ) so we suggested that the patient had hypoparathyroidism.

We started the treatment immediately with intravenous calcium (e.g.: $10 \mathrm{cc}$ of intravenous 10\% calcium gluconate solution infused over $30 \mathrm{~min}$ utes). This was followed by a continuous calcium infusion in the ICU (1-5 grams/liter normal saline) at $30-80 \mathrm{cc} / \mathrm{hr}$ until the serum calcium level reached $8.0 \mathrm{mg} / \mathrm{dl}$. Once the serum calcium level was stable and the patient could tolerate oral calcium, oral calcium carbonate was prescribed at 1-3 grams/day while the intravenous solution was slowly decreased. We inserted a central venous catheter to avoid irritation of peripheral veins and phlebitis. Precautions were taken to prevent seizures or larynx spasms.

\section{Discussion}

Multinodular goiter is a common clinical problem that usually develops during the late stage of goiter. Surgical resection is the treatment of choice for the majority of patients with benign multinodular goiter. The goal of surgical treatment in thyroid disease should be to eliminate the disease with low complication rates and minimize the need for reoperation for incidental recurrence in MNG [15]

RLN dysfunction and hypoparathyroidism are well-recognized important complications of thyroid surgery. Complication rates of thyroidectomy have a varying range for both RLN injury (0-9\%) and permanent hypoparathyroidism (1-7\%). Intensive effort should be spent to prevent these events, because they can be prevented with appropriate surgical technique during total thyroidectomy [1]

The risk of complications after extended resection is not significantly higher than after classic subtotal resection without identification of the nerve and parathyroids [16]. In our study, we are comparing between total and subtotal thyroidectomy in management of multinodular goiter as regard safety and effectiveness and postoperative complications.

As regard patient's age and gender: In our study larger percentages of the studied patients were females (65\% versus $70 \%)$. Age of patients undergoing total thyroidectomy ranged from 30 to 45 years with mean of 40.4 years while the age of patients undergoing subtotal thyroidectomy ranged from 35 to 45 years with mean of 39.25 years. There was statistically non-significant difference between the studied surgical techniques regarding age, gender or hormonal status.

While in comparable with Chahardahmasumi et al. [17] a total of 204 thyroidectomies were performed, with 102 in each group of total and subtotal techniques, there were 37 men $(18.13 \%)$ and 167 women $(81.86 \%)$ with a mean \pm SD age of $41.2 \pm 13.4$ years. There was no statistical significant difference between the two groups regarding age and sex.

As regard operating time: In our study, the mean operating time was $149.6 \pm 25.01$ minutes in the total thyroidectomy group compared to 134.5 \pm 21.94 minutes in subtotal thyroidectomy. There is statistically non-significant difference between the studied surgical techniques regarding operative time. Our results were compared with Sewefy et al. [18] who found no statistical significant difference between the two groups regarding age, sex and operative time.

As regard hematoma and wound site infection: In our study, just one patient (5\%) from those 
undergoing total thyroidectomy had hematoma and $(0 \%)$ from subtotal thyroidectomy had hematoma. No patient within both techniques had postoperative wound site infection.

In comparison with the study by Ciftci et al. [3] Hematoma developed in three $(1.9 \%)$ cases while wound site infection developed in one $(0.6 \%)$ patient in the bilateral subtotal thyroidectomy group. In the Total Thyroidectomy group, hematoma developed in three $(1.1 \%)$ cases while wound site infection developed in three $(1.1 \%)$ patients. No statistically significant differences were found between the two groups with respect to the development rate of hematoma and wound site infection $(p>0.05)$.

As regard RLN palsy: In our study, transient unilateral RLN palsy occurred in only one case $(5 \%)$ and no case had permanent RLN palsy $(0 \%)$ in group A. No patient had transient or permanent RLN palsy $(0 \%)$ in group $B$.

In comparison with Aspinall et al. [19] who reported a transient RLN palsy rate of $1.6 \%$ and a permanent RLN palsy rate of $0 \%$ after TT. The rate of transient and permanent RLN palsy was reported as $3.5 \%$ and $1 \%$, respectively, after BST.

While according to Barczynski et al. [20], the relative risk ratio of total thyroidectomy over subtotal thyroidectomy in the overall incidence of RLN palsyis 1.6, denoting higher incidence in total over subtotal, with $p$-value $<0.001$ which is statistically significant. And the relative risk ratio of total thyroidectomy over subtotal thyroidectomy in the incidence of temporary RLN palsy is 1.828 , denoting higher incidence in total over subtotal, with $p$-value $<0.001$ which is statistically significant. As regard permanent RLN palsy, the relative risk ratio of total thyroidectomy over subtotal thyroidectomy is 1.31 , denoting higher incidence in total over subtotal, with $p$-value of 0.149 which is statistically non-significant.

Our study reported higher incidence just in temporary RLN palsy in total thyroidectomy than subtotal thyroidectomy group, with $p$-value $<0.999$ but it was statistically non-significant.

In comparison with the studies done by Karamanakos et al. [1] who reported higher incidence of temporary and permanent RLN palsy in total thyroidectomy than subtotal thyroidectomy group, but it was statistically non-significant. Sewefy et al. [18] identified both RLNs successfuly in all patients of both groups with insignificant statistical difference $(p>0.04)$. No cases developed Transient
RLN palsy $(0 \%)$ in TT group VS. 8 cases in ST group $(7.1 \%),(p=0.004)$. No cases developed permanent RLN palsy in TT group (0\%) VS. One case $(0.9 \%)$ in ST group $(p=0.316)$.

As regard hypocalcaemia: In our study, after total thyroidectomy we noticed that one patient had temporary hypocalcaemia $(5 \%)$ and another one had permanent hypocalcaemia $(5 \%)$. No patients had temporary $(0 \%)$ or permanent $(0 \%)$ hypocalcaemia in patients undergoing subtotal thyroidectomy.

In comparison with Falch et al. [21] who reported that after thyroidectomy for large multinodular goiter, temporary hypocalcemia was present in 160 patients $(22.8 \%)$ with 91 patients $(13.0 \%)$ showing symptoms of hypocalcemia. Treatment with oral calcium was necessary in 92 patients $(14.6 \%)$, intravenous calcium in 36 patients $(5 \%)$ and vitamin $\mathrm{D}$ in 29 patients (4\%). This usually occurs about $36 \mathrm{~h}$ postoperatively. Persistent hypocalcemia was present in 48 of 702 patients $(6.8 \%)$. Ozbas et al. [11] reported postoperative hypocalcemia with rate of $4.7 \%$ that persistent in $1.3 \%$.

While Gulcelik et al. [22] reported that from total number of 696 patients who received subtotal thyroidectomy (Group 1, n = 289) and total thyroidectomy (Group 2, $\mathrm{n}=407$ ) transient and permanent hypocalcaemia rates were $16 \%$ and $5.8 \%$ in Group 1 and $8.5 \%$ and $3.1 \%$ for Group 2 respectively. Tezelman et al. [23] reported that transient and persistent hypocalcemia rates were $8.4 \%$ and $0.8 \%$, respectively, after TT and $1.4 \%$ and $0.4 \%$, respectively, after BST.

Our study reported higher incidence in both temporary and permenant hypocalcemia in total thyroidectomy than subtotal thyroidectomy group, with $p$-value $<0.999$ but it was statistically nonsignificant.

As regard hypoparathyroidism: In our study, no case had temporary hypoparathroidism $(0 \%)$. Only one patient had permanent hypoparathyroidism in total thyroidectomy group $(5 \%)$, while no patient had temporary or permanent hypoparathyroidism in subtotal type.

According to Barczynski et al. [20], the relative risk ratio of total thyroidectomy over subtotal thyroidectomy in the incidence of temporary hypoparathyroidism was 2.389 , denoting higher incidence in total over subtotal, with $p$-value 0.046 which was statistically significant. As regard permanent hypoparathyroidism, the relative risk ratio of total thyroidectomy over subtotal thyroidectomy 
is 1.48 denoting higher incidence in total over subtotal, with $p$-value of 0.007 which is statistically significant. They have shown that the risk of postoperative hypoparathyroidism is related to the extent of thyroid resection.

Rifaat et al. [24] check the parathyroid hormone serum level in all patients immediately in the postoperative period. No permanent hypoparathyroidism was seen in group ST patients but in one patient $(0.8 \%)$ of group $\mathrm{T}$; transient hypoparathyroidism occurred in two patients $(1.6 \%)$ of ST group and in one patient $(0.8 \%)$ in $\mathrm{T}$ group that improved on medications after 3 months with insignificant statistical difference $\left.(p\rangle_{-} 0.05\right)$.

Falch et al. [21] found no significant differences in terms of the rate of complication between TT and BST. Ciftci et al. [3] compared postoperative early-stage complications in patients who underwent BST and those who underwent TT for BMNG. They showed that there is no significant difference with respect to early-stage postoperative complications between TT and BST. However, TT has the advantage of avoiding the risk of disease recurrence and reoperation and eliminates any subsequent risk of malignant change in radiated thyroid glands. TT should therefore be considered for treating BMNG.

Like many other studies, our study results illustrated that using TT for benign thyroid diseases can be done with little morbidity. The most important factor in decreasing morbidity in thyroid surgery is the surgical technique employed. We believe that during the mobilization and dissection of the thyroid lobes, exposing the RLN, employing effective hemostasis during operation to ensure clear operation, viewing the four parathyroid glands, and protecting their perfusion vessels may help to reduce complications.

\section{Conclusion:}

The advantages of total thyroidectomy include adequate eradication of the disease, prevention of recurrent goiter and avoidance of the need for completion surgery in case of occult malignancy, but it is associated with higher morbidity (postoperative thyroidectomy complications: RLN palsy and hypoparathyroidism) and the need for lifelong replacement therapy (L-thyroxin supplementation).

\section{References}

1- KARAMANAKOS S.N., MARKOU K.B., PANAGOPOULOS K., et al.: Complications and risk factors related to the extent of surgery in thyroidectomy. Results from 2,043 procedures. Hormones (Athens), 9 (4): 318$25,2010$.
2- YANG W., SHAO T., DING J., et al.: The feasibility of total or near-total bilateral thyroidectomy for the treatment of bilateral multinodular goiter. J. Invest. Surg., 22 (3): 195-200, 2009.

3- CIFTCI F., SAKALLI E. and ABDURRAHMAN I.: Total versus bilateral subtotal thyroidectomy for benign multinodular goiter. Int. J. Clin. Exp. Med., 8 (3): 4596-600, 2015.

4- VEYSELLER B., AKSOY F., DEMIRHAN H., et al.: Total thyroidectomy in benign thyroid diseases. Kulak Burun Bogaz Ihtis Derg., 19 (6): 299-303, 2009.

5- WILHELM S. and MCHENRY C.: Total Thyroidectomy Is Superior to Subtotal Thyroidectomy for Management of Graves' Disease in the United States. World Journal of Surgery, 34: 1261-1264, 2010.

6- COLAK T., AKCA T., KANIK A., et al.: Total versus subtotal thyroidectomy for the management of benign multinodular goiter in an endemic region. ANZ J. Surg., 74 (11): 974-978, 2004.

7- SERPELL J.W. and PHAN D.: Safety of total thyroidectomy. A NZ J. Surgy, 77 (1-2) : 5-9, 2007.

8- ELENI I.E., MICHAEL S.P., NIKOLAOS L., et al.: The efficacy and safety of total thyroidectomy in the management of benign thyroid disease: A review of 932 cases. Can J. Surg., 52 (1): 39-44, 2009.

9- FÜHRER D., BOCKISCH A. and SCHMID K.W.: Euthyroid Goiter With and Without Nodules Diagnosis and Treatment. Dtsch Arztebl Int., 109 (29-30): 506-516, 2012.

10- BRAUN E.M., WINDISCH G., WOLF G., et al.: The pyramidal lobe: Clinical anatomy and its importance in thyroid surgery. Surg. Radiol. Anat., 29: 21-27, 2007.

11-OZBAS S., KOCAK S., AYDINTUG S., et al.: Comparison of the complications of subtotal, near total and total thyroidectomy in the surgical management of multinodular goitre. Endocr. J., 52 (2): 199-205, 2005.

12- COHEN-KEREM R., SCHACHTER P., SHEINFELD M., et al.: Multinodular goiter: The surgical procedure of choice. Otolaryngol. Head Neck Surg., 122 (6): 848-850, 2000.

13- LEFEVRE J.H., TRESALLET C., LEENHARDT L., et al.: Reoperative surgery for thyroid disease. Langenbeck's Archives of Surgery, 392: 685-691, 2007.

14- KORUN N., AS CI C., YILMAZLAR T., et al.: Total thyroidectomy or lobectomy in benign nodular disease of the thyroid: Changing trends in surgery. Int. Surg., 82 (4): 417-9, 1997.

15- CITGEZ B., ULUDAG M., YETKIN G., et al.: Changes in the choice of thyroidectomy for benign thyroid disease. Surg. Today, 43 (6): 625-31, 2013.

16- CHRISTOU N. and MATHONNET M.: Complications after total thyroidectomy. J. Visc. Surg., 150 (4): 249256, 2013.

17- CHAHARDAHMASUMI E., SALEHIDOOST R., AMINI M., et al.: Assessment of the Early and Late Complication after Thyroidectomy. Advanced Biomedical Research, 8: 14. PMC6425745, 2019.

18- SEWEFY A., TOHAMY T., ESMAEL T., et al.: Intracapsular total thyroid enucleation versus total thyroidec- 
tomy in treatment of benign multinodular goiter. A prospective randomized controlled clinical trial. International Journal of Surgery. Volume 45, September 2017, Pages 29-34, 2017.

19- ASPINALL S., OWEIS D. and CHADWICK D.: Effect of surgeons' annual operative volume on the risk of permanent Hypoparathyroidism, recurrent laryngeal nerve palsy and Haematoma following thyroidectomy: Analysis of United Kingdom registry of endocrine and thyroid surgery (UKRETS). Langenbeck's Archives of Surgery volume 404, 28 June 2019, pages 421-430, 2019.

20- BARCZYN'SKI M., KONTUREK A., HUBALEWSKADYDEJCZYK A., et al.: Ten-Year Follow-Up of a Randomized Clinical Trial of Total Thyroidectomy Versus Dunhill Operation Versus Bilateral Subtotal Thyroidectomy for Multinodular Non-toxic Goiter. World Journal of Surgery volume 34, 23 September 2017, pages 12031213, 2018.
21- FALCH C., HORNIG J., SENNE M., et al.: Factors predicting hypocalcemia after total thyroidectomy - A retrospective cohort analysis. International Journal of Surgery, Volume 55, July 2018, Pages 46-50, 2018.

22- GULCELIK M., DOGAN L., AKGUL G., et al.: Completion Thyroidectomy: Safer than Thought. Oncology Research and Treatment. Vol. 41, No. 6, June 2018, pages 386-390, 2018.

23- TEZELMAN S., BORUCU I., SENYUREK GILES Y., et al.: The change in surgical practice from subtotal to neartotal or total thyroidectomy in the treatment of patients with benign multinodular goiter. World J. Surg., 33 (3): 400-5, 2009.

24- RIFAAT M., SABER A. and HOKKAM E.N.: Total versus subtotal thyroidectomy for benign multinodular goiter: Outcome and complications. J. Curr. Surg., 4 (2): 40-45, 2014.

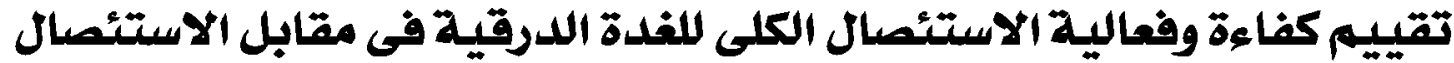

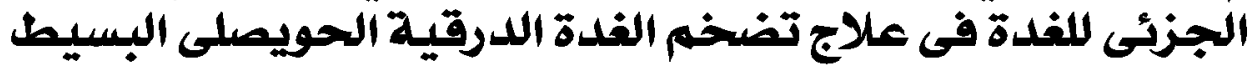

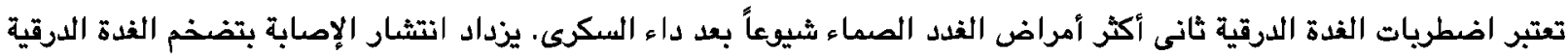

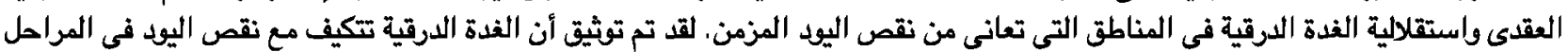

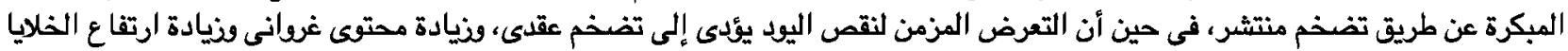
الجرييية.

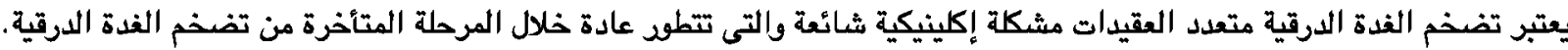

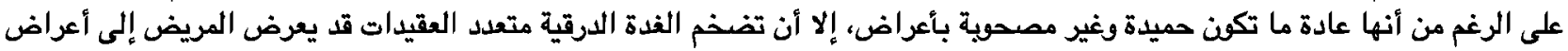

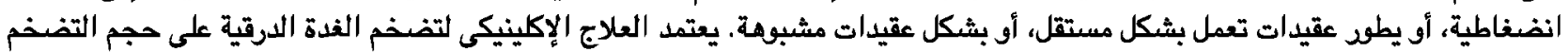
وعلاماته وأعراضه والأسباب الكامنة المحتملة.

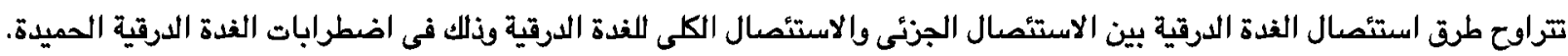

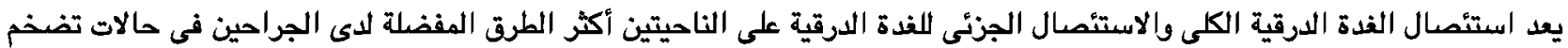

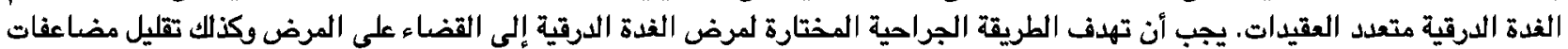

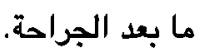

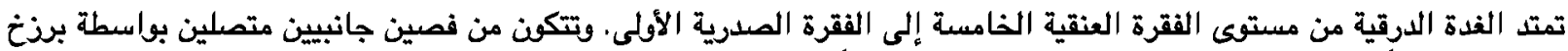

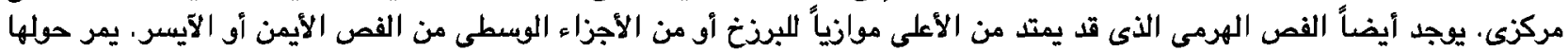

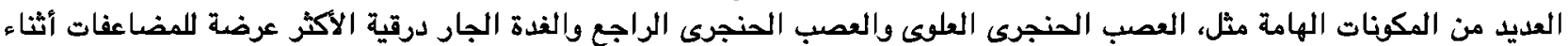

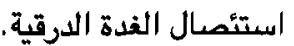

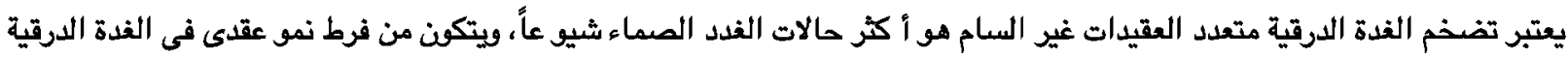

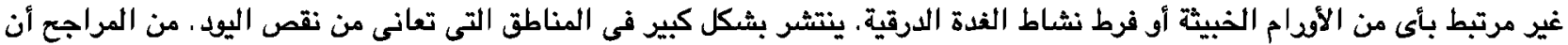

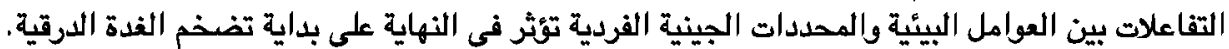

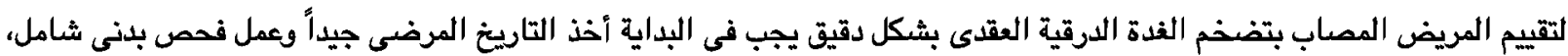

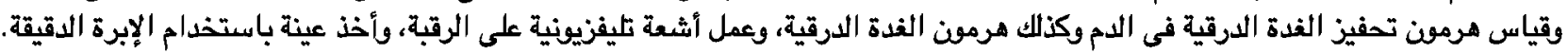

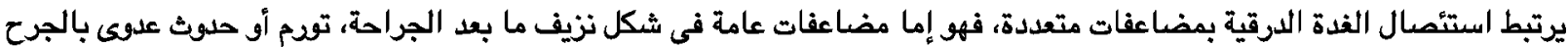

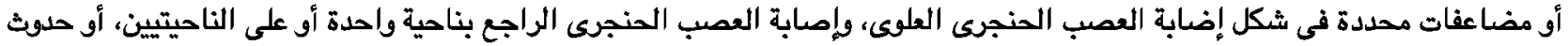




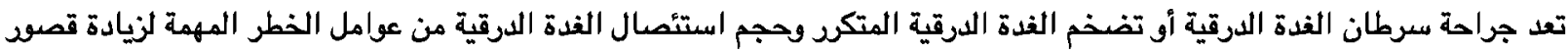

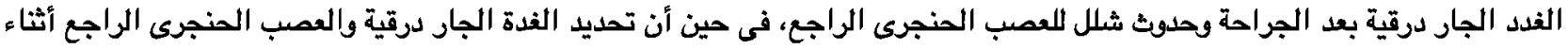
العملية ومدى خبرة الجراحين القائمون بعملية استئصال الغدة الدرقية من العوامل التى تقلى التل من خطر الإصابة.

في دراستنا، نقارن بين استئصال الغدة الدرقية الكلى والجزئى فى إدارة تضخم الغدة الدرقية متعدد العقيدات فيما يتعلق بالسلامة والفعالية ومضاعفات ما بعد الجراحة.

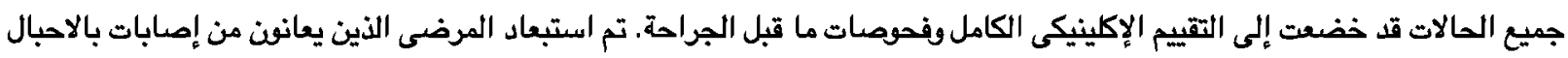

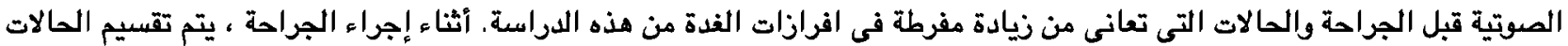

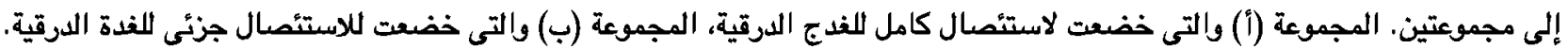
تم تثييت جميع العوامل والمتغيرات باستثناء التقنية الجراحية. لاستئ.

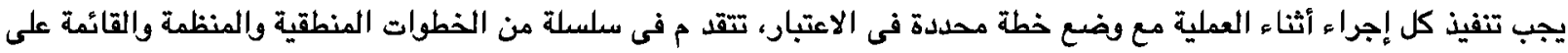

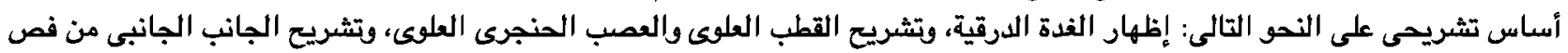

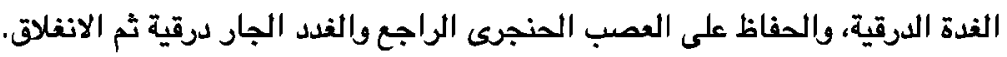

توجد فروق ذات دلالة إحصائية غير معتد بها بشكل ثابت بين التقنيات الجراحية المدروسة فيما يتعلق بالعمر أو الجنس أو الحالة الهرمونية.

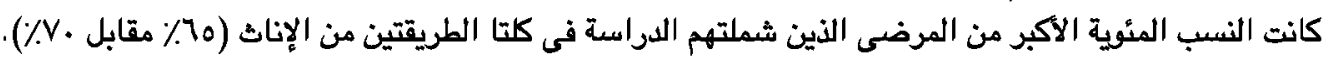

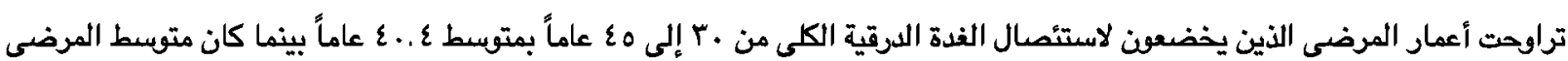

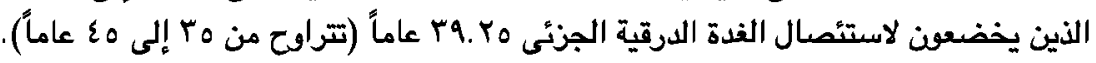

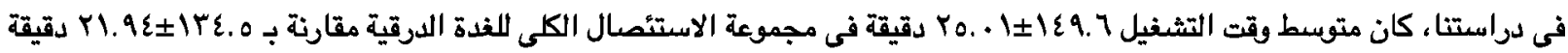

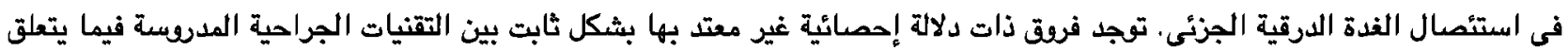

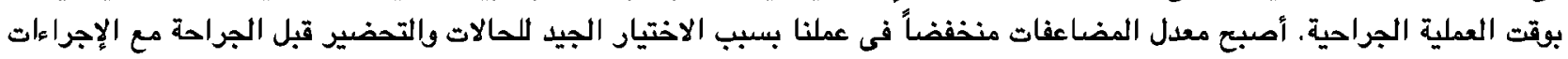

الجراحية الدقيقة.

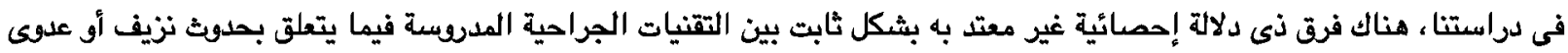

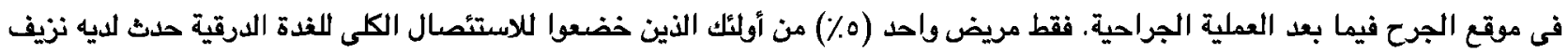

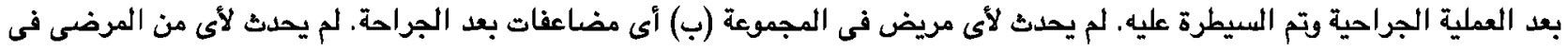

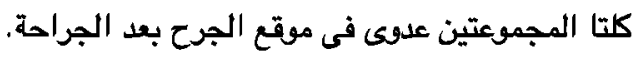

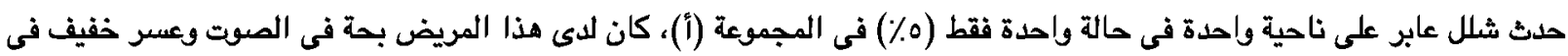

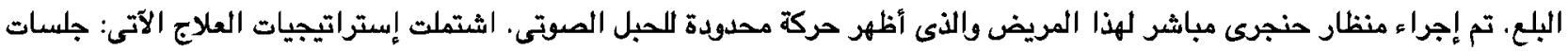

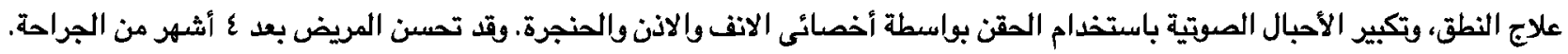

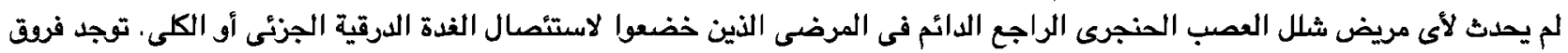

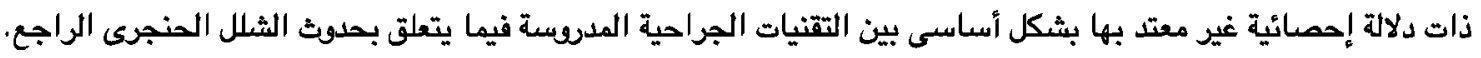

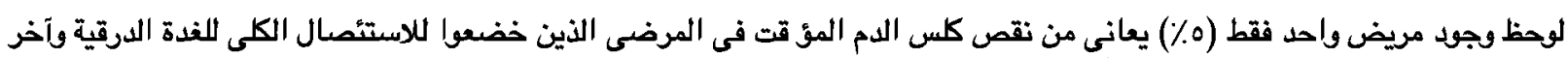

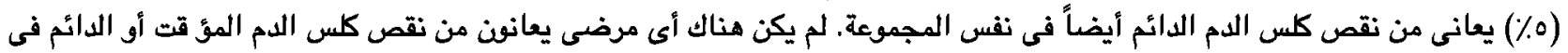

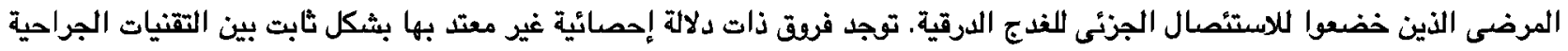

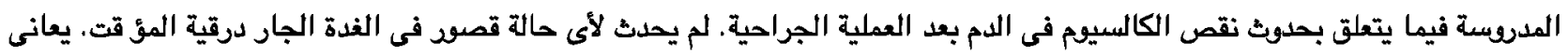
مريض واحد فقط من قصود الغدة الجار درقية الدائم فى الاستئصال الكلى اللغدة العية الدرقية.

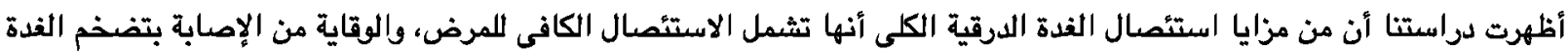

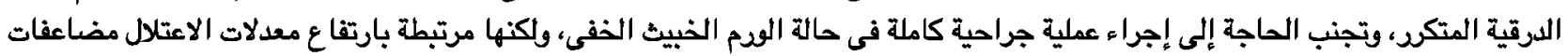

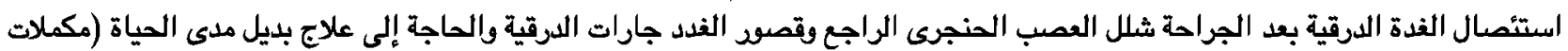

